Gadjah Mada International Journal of Business

May-August 2008, Vol. 10, No. 2, pp. 139-159

\title{
PRODUCT DEVELOPMENT CATEGORIZED AS INDEPENDENT STRATEGIC AND INNOVATIVE PRACTICE Case from Indian Manufacturing
}

\author{
Himanshu Dutt
}

In recent time, Indian manufacturing has seen technologically intensive and resource optimization based initiatives to satisfy competitive urge and to build or sustain market position. This they do by developing products either strategically or innovatively, but that is hardly distinguished or seen as a separate approach to product development. Strategically, product development is resource optimization based while innovatively, it is product differentiation focused.

This paper outlines the strategic and innovative approach to product development and analyzes sector specific role of each in product development. The study is undertaken with nine product development team-leaders and resource-heads, three of each from automobile, steel and textile. It is concluded that textile is strategically skewed toward product development whereas automobile is inclined towards innovative orientation. The biggest limitation of this study is smaller sample-size because respondents are reluctant to disclose new technical initiatives and composition of product development.

Keywords: automobile; India; innovative product development; manufacturing; product development; steel; strategic product development; textile

\section{Acknowledgment:}

The author gratefully acknowledges the comments of anonymous reviewers for their insightful, constructive suggestions and the efforts of Dr. Hotniar Siringoringo, Lecturer at Gunadarma University, Indonesia for her assistance in reviewing the manuscript and publishing of this paper. 
Gadjah Mada International Journal of Business, May - August 2008, Vol. 10, No. 2

\section{Introduction}

Exploiting product-market opportunities for diversifying risk and business expansions have directed organizations to focus on new product development activities (Exhibit I). Threat of shorter product life cycle, shrinking time-to-market, and shifts in buyer's taste have made organizations to think hard for product differentiation and resource optimization. However, during this process the organizations place emphasis on product differentiation and resource optimization practices accordingly. They rarely differentiate what is most basic to product development - product characteristics or optimal utilization of resources. It is a combination of both, which varies among organizations in the same sector. This combination represents product development capabili- ties influenced by either a strategic action or innovative function. The difference being strategic factors encompass resource-based view while innovative factors relates to product characteristics.

Product development thus may change among organizations in the same industry producing the same product. Even the production process may vary with different time consumption patterns and designing requirements for the product targeted at the same set of audience. These decisions to innovate and develop products, production process setting and marketing outcome are strategically conceived and innovatively produced.

Strategic practice in product development identifies needs for developing new products, such as for market share expansion, early mover advantage, market leadership in exist-

\section{Exhibit I. Product Development Initiators}

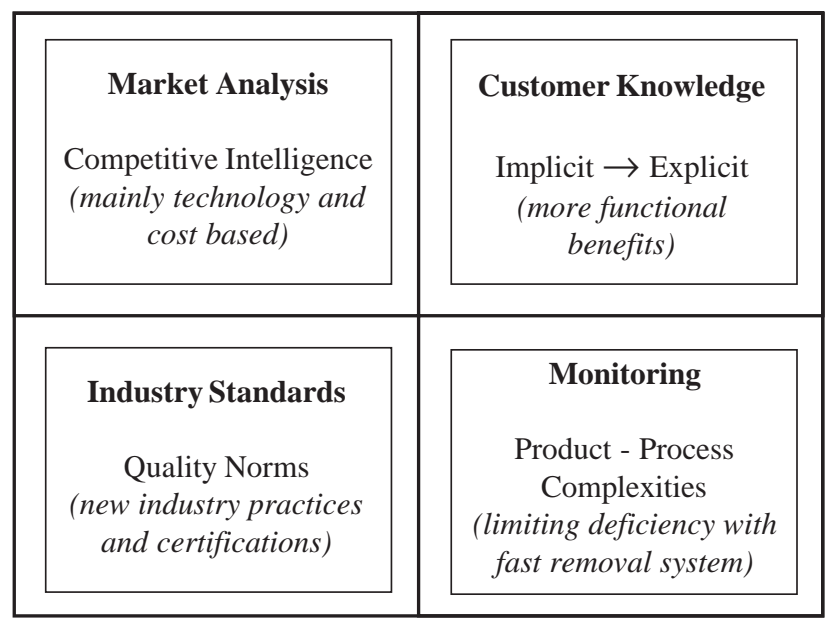


Dutt-Product Development Categorized as Independent Strategic and Innovative Practice

ing market and industry competition. On the other hand, innovative practice in product development acts as a vital determinant of product development function. It is focused upon reducing product development time and costs, offering a high degree of product benefits (as problem-solving), and giving steer products to customers. It is a function of peoples' intelligence to configure products that could better meet the perceived and tacit demand.

This study differentiates strategic and innovative practices in product development as two separate variables of product development in Indian manufacturing with respect to the foci of these two practices on product development, and studies their components relevant to the development function.

\section{Review of Literature}

Product development refers to the practice of converting an idea into marketable product that includes stages of activities (Exhibit II). It is widely accepted to be a strategic tool for competitiveness that could be attributed to its strategic nature and innovative oriented characteristics. However, both strategy and innovativeness as a function of product development have been changing drastically. Successful products are not technologically driven (strategic decision to use technology as main the driver to develop products) anymore, and good designs (productbased characteristics) do not necessarily guarantee success. Both - strategic and innovative perspectives thus can not function in isolation.

\section{Exhibit II: Outlay of Product Development Stages}

Stage 1: Analysis of Market Opportunity

- Analyzing Competition and Industry Standards

- Appraising Capabilities and Resources

- Assessing Organizational Standing

Stage 2: Development and Testing

- Diagnosing Process

- Developing Mechanism

- Deriving Model

- Recording technical feasibility

- Validating for testing

Stage 3: Commercialization

- Sample Testing

- Correcting Reviews

- Market Development and Sales

Stage 4: Monitoring Product Life Cycle

- Innovative marketing practices

- Sustaining PLC through product support

- Prolonging the maturity period

- Introduce related diversification before product grey 
Manufacturing organizations develop new products offered to the industry and the world (nearly half or 10 out of 21 new product projects), but they have not been eager for radical change in the past (Ettlie and Subramaniam 2004). Nearly 50 percent of the new products introduced each year fail. One of the primary reasons is the absence of innovativeness (Sethi et al. 2001) behind strategic issues.

\section{Product Development Perspectives}

Moorman (1995) suggests that product development is an 'organizational activity' with all functional areas pooling their expertise to develop products. It is focused upfront on 'customer needs' and on the downstream on desired 'outputs' (Bhattacharya et al. 1998). It is also considered to be an 'organization's business strategy' (Enright 2001).

Product development is a 'knowledge-producing' (Madhavan and Grover 1998) and 'problem-solving' (Thomke and Fujimoto 2000) activity. It is more a 'cognitive process' than a 'social process' of merely managing teams. Tatikonda and Montoya-Weiss (2001) view product development as process of 'innovation' as depending upon the 'information-processing' capabilities of product development teams in terms of relationships among the organizational processes (crossfunctional teams) (Verona 1999; Xie et al. 2003; Olin and Shani 2003;
Sherman et al. 2005), product development capabilities (Song and Parry 1996), critical uncertainties (like perceived technological uncertainty) and operational market performance (Pun and Chin 2005). This entails that broadly product development requires strategic consideration of managing organizational functions, which is matching its capabilities and organizing for resources, planning for uncertainties and adopting innovative marketing programs for development.

According to $\mathrm{Li}$ and Cavusgil (2000), the alignment of 'customerlearning' process or knowledge (Joshi and Sharma 2004), competitor learning process and the marketing-R\&D interface are important for a more functional product depending upon how the organization processes its market knowledge competence and with what level of intensity. But, it is Ledwith (2000) who categorizes product development from cognitive to social dimensions and from 'technological' perspectives to market knowledgecompetence. This is then cited by Montoya, Weiss, and Calantone(1994)and Perks et al. (2005), focusing on three product design roles in developing products functional specialism; multifunctional team; and a process leader. It is Veryzer and Mozota (2005) who modify this design approach to include customer focus. This design-based approach focused on customer perspective is labeled as user-oriented design. Organizational factors that impact on the success of NPD can be summarized under cooperative competency model 
Dutt-Product Development Categorized as Independent Strategic and Innovative Practice

that is based on trust, communications, and coordination (Sivadas and Robert 2000). The product development conceptual framework thus can be said to be the collection of metrics upon which depends the product development capability of firm. However, these metrics are numerous and not all organizations consider all of them to develop products.

\section{Product Development as Strategic and Innovative Function}

Product development has a variety of potential benefits ranging from first-mover advantage (Hamel and Prahalad 1991; Kotler 1998), extended sales lives (Moorman 1995; Bennett and Savani 2004), greater customer responsiveness (Hill 1998; Copper 2001) brand identity and market value (Joshi and Sharma 2004), intellectual capacities development and exploitation (Krishnan and Ulrich 2001). However, the need for continuous product development has arisen due to the fact that there is a continuous shift in buyer's taste and preferences (Jhone and Snelson 1990; Hart 1992; Bilington et al. 1998). This has led to shorter product life cycles (Datar and Clark 1997; Filippini et al. 2004; Rzakhanov 2004). The marketers make strategic shifts in their development cycle to introduce innovative products with significantly reduced time-to-market practices (Davis et al. 2001). Thus, new product market performance is dependent upon the assimilated mix of external and internal dynamics that assists in the reasoning of market knowledge competence (Zirger and Maidique 1990; $\mathrm{Li}$ and Calantone 1998; Calantone et al. 2003), such as knowledge about customer and competitors, and the interaction between marketing and $\mathrm{R} \& \mathrm{D}$ functions on product-marketissues and technology.

New product development is an intellectual process (Drucker 1985; Levitt 1989). It depends upon how intelligently the need for replacing or modifying the existing products should take place. It requires a strong market interface and smooth customer orientation before the products could be labeled as 'knowledge products' (Zack 1999; Skyrme 1999). It is a strategic assimilation of a firm's resources and knowledge to innovate, which depends upon the spirit of corporate and individuals (Mintzberg et al. 1998) to develop new products.

To assess the innovative spirit of corporate and individuals and their mutual relationship, an empirical study is conducted in Bhilai Steel Plant, India. The study hypothesizes on the basis of two aspects: strategic corporate orientation and innovative urge of employees (Kamath et al. 2000). The study identifies different components for measuring organization on strategic decisions and employee innovativeness.

A brief mention of knowledge management concept (Nonaka and Takeuchi 1995; Davenport and Prusak 1998 ) is worth a mention. They view product development as teams sharing success and failure experiences, em- 
ploying knowledge to explore new possibilities and sharing new knowledge more continuous and acquired in the process. This aspect is strategic in nature (Enright 2001).

On other hand, innovation function of product development (Moorman and Miner 1998) shall be the response to the challenge, discomfort, inconvenience or unpleasantness confronting the customers and organizations. Customer needs are rapidly shifting from mass produced products to more customized ones. The variety is high, differentiations are growing, and both local and global organizations are countering each other for fragmented growing niche markets. (Bond III and Houston 2003). Therefore, the knowledge-based cognitive approaches strategically modified to suit product development function can be looked upon as more enterprising and vivid.

Ettlie and Subramaniam (2004) assert that strategic orientation requires a firm to become competitive, and innovativeness is the vehicle that infuses such competitiveness. Clark and Fujimoto (1991) and Calontone et al. (2003) also have shared similar views but listed different parameters to support their statements.

\section{Rationales for Selecting Manufacturing and Product Development}

New product development in Indian manufacturing organizations is more mechanical rather than technical
(Venkataramani 2004), and with the pace of economical development after liberalization in 1991 (Noble 2006), the complexity of the mechanical production has grown multifold (Venugopal 2005). These determinants are helpful to analyze whether the product development depends more on strategic function or innovative characteristics.

The share of manufacturing in the GDP has remained stagnant for over 15 years since 1990 (15.8\% in 1991) at around 17 percent (DSIR and FICCI). The present challenge before industry and government is to grow the manufacturing sector at 14 percent annually for the next 10 years from the present low of seven percent (average rate per annum) in order to raise the sector's contribution to GDP from 18 percent to 30 percent (National Manufacturing Competitiveness Council Report 2006). The industry is also developing fast as an excellent base for prototyping, testing, validating and productionizing of products (ACMA 2005-06).

According to SIAM (2007), Indian automobile industry's performance in the year 2004-05 showed encouraging results for all segments of the automobile industry. The industry registered a growth of around 16 percent in numbers over the year 2003-04. In the year 2006-07 until April, the industry has recorded a 1.3 percent decline in the performance with overall average annual potential estimated at $\$ 390$ billion for the last three years. 
Dutt-Product Development Categorized as Independent Strategic and Innovative Practice

The impressive growth of the steel sector continued for the fourth consecutive year. The increasing presence of Indian steel companies in the global market with a wide-ranging export basket that includes complex and technologically sophisticated product is showing the vital sign of competitiveness. The production trend grew highest in the year 2005-06 at 16.21 percent in 2005-06 from 15.91 percent in the year 2003-04. The International Iron and Steel Institute (IISI) ranked India as the seventh largest steel producer in the world with an overall production of about 40 million ton (MT) in 2006. According to its estimation, India's steel production during April 2006-February 2007 grew 10.1 percent at $44.3 \mathrm{MT}$ as against 40.237 MT in the corresponding period of previous fiscal year (NIC 2007).

Textiles account for 14 percent of India's industrial production and around 27 percent of its export earnings. The sector has shown a 3.66 percent CAGR over the last five years. The textile and clothing sectors are the largest employers after agriculture, and their importance in India's economy is recognized for their contribution to industrial production and export earnings. The production of fabrics has increased by 9.25 percent in 2005-06 over the corresponding period of previous year at 8.20 percent. In U.S. dollar terms, the value of exports increased by 21.8 percent in 2005-06. The production of fabrics from all mills, handlooms, power looms and other sources showed huge increments from a total figure of 40,233 (in million squared meters) in the year 200001 to 49,577 in the year 2005-06. Besides, India's cotton textile industry has quite a high export potential. Cost competitiveness is driving the penetration of Indian basic yarns and grey fabrics in international commodity markets. India accounts for 15 percent of the world's total cotton crop production and is the largest producer of silk with large pool of skilled low-cost textile workers, experienced in technological skills (Association of Chambers of Commerce 2006).

This research selects aforementioned manufacturing industries (i.e., automobile, steel and textile industries) to understand the product development determinants of strategic and innovative contexts in India. While the manufacturing contributes over 16 percent to India's GDP, these three industries collectively contribute more than 9 percent to economic growth (FICCI 2006).

\section{Study Objectives}

The objective of this study is to analyze strategic and innovative perspectives in product development in Indian automobile, textile and steel sectors. Related determinants of product development to both the perspectives are also analyzed and ranked in the order of significance to product development. 
Gadjah Mada International Journal of Business, May - August 2008, Vol. 10, No. 2

The following hypotheses are developed to study the laid objectives.

H1: Strategic perspective in product development is equal in automobile, textile and steel industries.

H2: The importance of innovation in product development is equal for automobile, textile and steel industries.

\section{Methodology}

This research is exploratory in nature that draws sample from three manufacturing industries-automobile, textile and steel. One organization from each of these three industries is included in the sample. The top performing organization from each industry (for the period 2005-06) as evaluated in terms of net assets, volume of production, and annual turnover from the balance sheet are taken as the basis for selection as sample. Nine executives from each three organizations are selected. In other words, three respondents, each from the three organizations, are contacted. However the Section $\mathrm{C}$ of questionnaire is administered only to one executive from each of the three organizations who is mainly the product manager/project/team leader responsible for product development operations.

Closed-end structured Likert scale based questionnaire is administered to the respondents. Descriptive statistics is employed to analyze and interpret the results.

\section{Scale Definition}

The instrument designed for this study consists of Parts A, B and C in the survey. Part A covers the respondent's profile, such as name, education, designation, department, work experience, budget or expenditure on product development and the skills of the product development team members. This is a closed-end structured part.

For Part B, the survey employs 15 point scale (Likert scale) for each statement; 1 being "strongly disagree" and 5 being "strongly agree" for Part A of the questionnaire.

For instance, consider the following statement for strategic perspective:

In your organization, practical experience is more important than theoretical knowledge.

1 2 3 4 5

Similarly, consider the following statement for innovative perspective: I always encourage my development team to come up with new ideas or improvements in product development process on a continuous basis.

1 3 5

Part C of the survey deals with some other variables of product development as related to production and product development; and the significance of determinants of product development in respective organizations. 
Dutt-Product Development Categorized as Independent Strategic and Innovative Practice

For example, consider the following statement:

Rate the metrics listed below on the scale of 1-5 to show their significance in new product development process in your company; 1 being "lowest" and 5 being "highest".

1. Market potential and competitiveness

1 2 3 4 5

2. Technology changes (production methods, processes, and techniques)

1 2 3 4

3. Experience, creativity and innovation(such as configuring better value in product design)

1 3 4 5

4. Managerial interests and execution styles

1 2 3 4 5

5. Pressure from suppliers and customers

1 2 3 4 5

\section{Limitations of Study}

The basic limitation of this study is that one company out of three different manufacturing sectors is small sample to draw the inference. Also, this study restricts to three industries (i.e., textile, automobile and steel industries) that are not sufficient to generalize the product development determinants for the whole manufacturing sector in India.

\section{Analysis and Results Interpretation}

The questionnaire administered to the respondents is divided into three parts: Part A, covering the respondent's profile; Part B that facilitates a comparison of product development determinants based on strategic orientation and employee innovativeness in the selected manufacturing organizations in India; and the Part $C$ that identifies some other relevant variables for successful product development.

Part A of the survey reveals that out of nine respondents, only one has a doctorate degree (in automobile), and majority has engineering degrees with textile having least of all. Nevertheless, the textile sector is found to have the largest total members in the product development team, followed by automobile and steel sectors, respectively. Automobile has the highest level of education requirements (engineers) for product development and also the highest ratio of product development budget (to that of overall $\mathrm{R} \& \mathrm{D}$ budget). However, in terms of experience and university education, textile has the highest number of years of experience at a maximum of 38.3 years and four university degree holders in the product development team. Similarly, the automobile and steel are more capital intensive sectors than textile with turnover more than Rs500,000 Crores.

In the Part B of questionnaire, the analysis starts with a strategic per- 
spective of the organization toward product development that shall help to compare the strategic perspective in developing products for all of the three sectors and to report the ranking. Standard error for textile is 0.1930 , the lowest in comparison to automobile (0.3138) and steel (0.3553).

Figure 1 indicates the positions of automobile, textile and steel sectors on a standard error bar to represent that strategic perspective in product development in all of the three sectors is not equal and that textile has higher strategic perspective in product development than do automobile and steel.

However the standard deviation shows that automobile (1.08), textile (0.66) and steel (1.23) are tightly bunched together and the bell-shaped curve is steep, meaning that the standard deviation is small. The standard deviation does not vary too much and hence does not indicate much variability. However, it can be concluded from the data that textile has the highest strategic inclination in product development, followed by automobile and steel. Thus, the first hypothesis stands rejected.

The next section, Part B, aims at understanding the organization's innovative perspective toward new product development to analyze which sector out of the selected three sectors can be attributed the highest in innovative based product development.

Figure 1. Strategic Perspective to Product Development among Automobile, Textile and Steel.

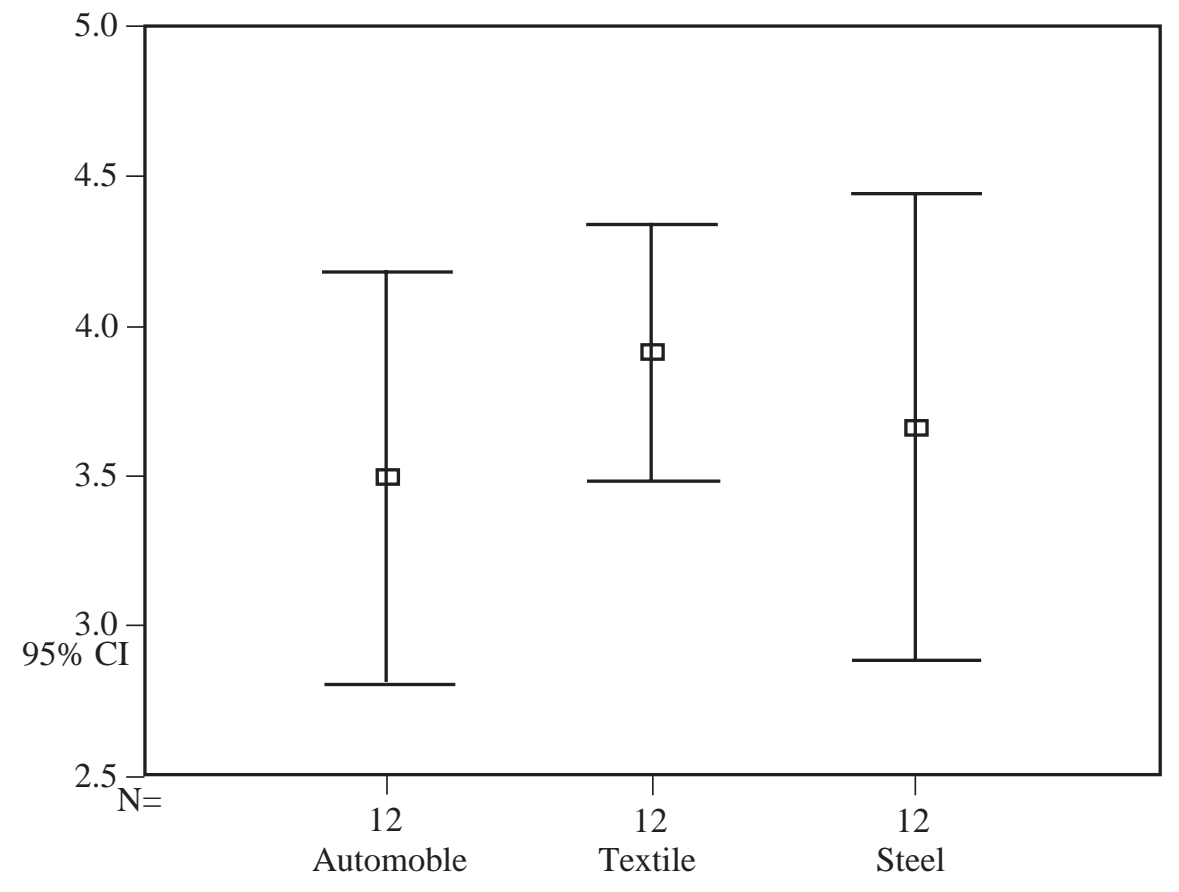

148 
Figure 2. Innovative Perspective to Product Development among Automobile, Textile and Steel.

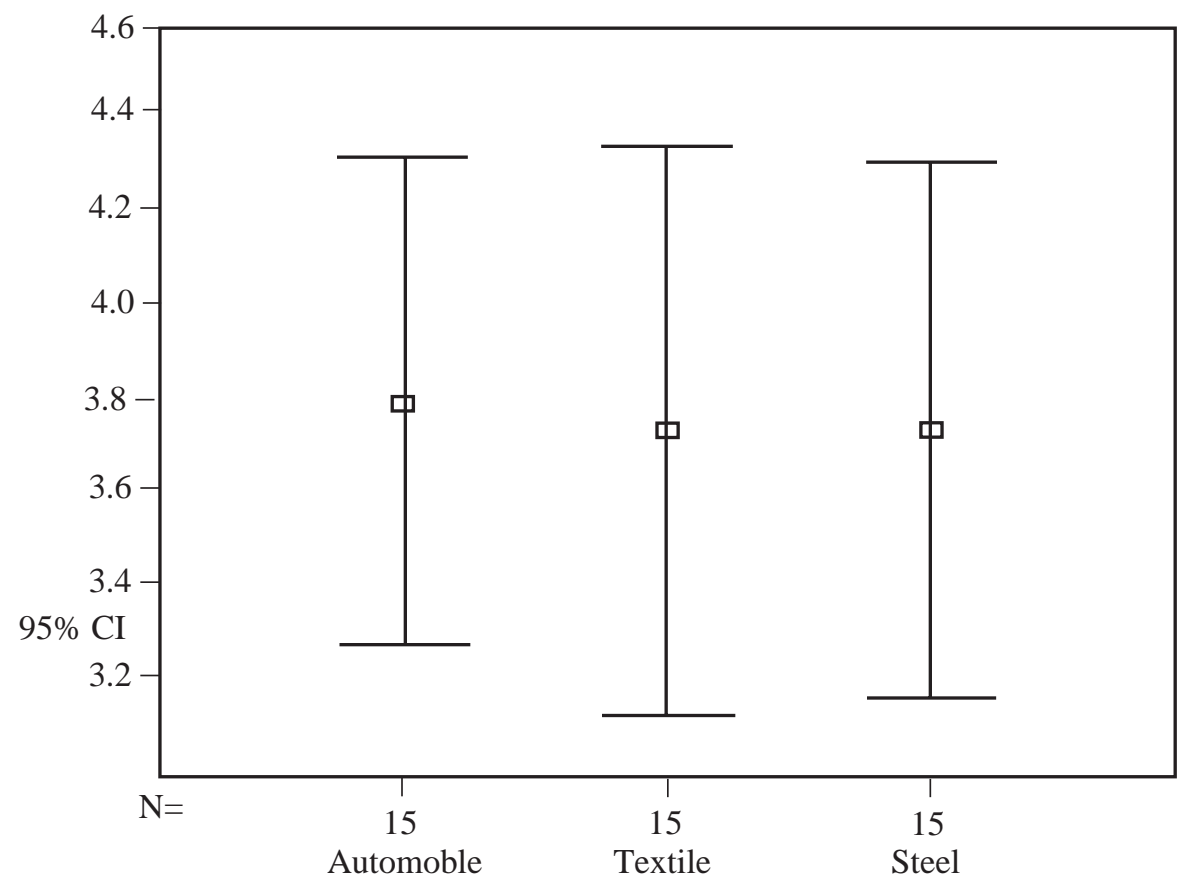

Figure 2 indicates the positions of automobile, textile and steel sectors on a standard error bar. It shows that the innovative perspective in product development is not equal among automobile, textile and steel sectors. The standard deviations calculated for automobile (0.94), textile (1.09) and steel (1.03) indicate no significant variability. There is not much difference in standard error for any of these organizations; however, automobile has the lowest at 0.2430 followed by textile (at .2840) and steel (.2667). This rejects the second hypothesis, meaning that the significance of innovativeness in product development is highest in automobile, followed by steel and textile.

The final conclusion interpreted from Part B is that strategic and innovative perspectives in product development are independent and separate practices, and that new product development varies among manufacturing sectors on these two perspectives as discussed.

The analysis for Part $\mathrm{C}$ of the questionnaire deals with a total of 20 variables that have been identified and grouped under the following four headings (internal, external, process-based, and on-importance bases). They represent a mix of strategic-innovative variables of product development. 
Gadjah Mada International Journal of Business, May - August 2008, Vol. 10, No. 2

1. Internal factors' contribution to the product development process.

The analysis has been done using the Delphi technique to evaluate the respondents' opinions as rated by them on the scale of 5 . The descriptive statistics below clearly reveals (through mean value) that the organizational culture and politics (5.0) contributes maximum to the product development process, then followed by customer focus (3.33); strategy (3.0); cross-functional integration (2.66); and the least important is hierarchy of structure (1.0).

2. External Factors' contribution to the product development process. Strategic alliances and technology transfers contribute the highest (4.33) to the product development process. Technology inputs (4.0) are the next most contributing variable to the process, followed by market reforms (3.33); supplier integration (2.0) and product adaptation requirements (1.33).

3. Initiation of the product development process. Creative urge for the first mover advantage (4.66) and market potential and competency (4.33) drive the product development process in the company most of the time. Subsequently, the contributions of product maturity (in PLC) (2.66), upgraded technological infrastructure (2.33) and stakeholder interests and involvement (1.0) to the development process have been reported.
4. The significance of product development determinants in organizations. Experience, creativity and innovation (4.33) are the most significant determinants of product development in all of the three manufacturing industries. The next highest significant determinant of product development is technological changes (3.66) that could be due to changes in production process or some new technologies. The other determinants are market potential and competitive strength of organization (3.0); product manager interests and styles (3.0) of handling product development projects in the organization; and finally, the pressure that organizations get from their members in the supply chain and their customers (1.66).

Among all of the internal contributing variables, 'organizational culture and politics' contributes maximum to the product development whereas 'hierarchy of structure' contributes the least. Among all of the external factors, 'strategic alliances and technology transfers' is most concerned in the product development whereas 'product adaptation requirements' is the least considerate factor. Among the determinants that initiate the product development process in organizations, 'creative urge for first mover advantage' is weighted as the most important initiator of product development while 'stakeholder interests and involvement' to the development process is reported as the least 
Dutt-Product Development Categorized as Independent Strategic and Innovative Practice

preferred by the respondents. Experience, creativity and innovation top the list of most significant variables in product development.

\section{Conclusions}

The paper concludes that there is a difference between strategic and innovative perspectives in product development. Strategic perspective is a theoretical concept concerned with product based decision-making while innovative perspective is drawn on product characteristics, benefits and features. The paper clarifies that textile sector uses strategic parameters in product development while automobile uses innovative ones. However, a link of the degree of difference between these two can not be established, and the degree of impact also can not be ascertained. The difference with respect to these two perspectives asserts that product development encompasses an integrated view of both perspectives albeit in a varying degree of combination. Such a combination differs in Indian manufacturing, depending upon the sector in which an organization operates.

The paper also concludes that the key product determinants based on strategic and innovative perspectives are culture and politics internally, and technology externally. The improvement in internal or organizational cultural outlook and politics shall mean more effective product development. This requires magnifying and managing cultural diversities effectively to establish more significant relationship hierarchies and line-staff authorities. Similarly, recognizing and planning strategic alliances for technology transfers or inventing technologies or the processes are important for faster, better and cheaper product development.

The primary driver for initiating the process of product development mainly stems from the urge to become the first mover in the market. The first mover advantage establishes a temporary monopoly and market leadership, until imitation follows and competitiveness spreads. It is important to understand what makes the product unique (differentiation) and transforms the idea into the product. This also requires planning for time-based product development before the market runs dry or the product per se becomes obsolete. The manufacturing organizations should hence focus on reducing time-to-market and avoiding prolonged product life cycles.

Employee experience, creativity and innovation are the most significant determinant of product development in the manufacturing industry. Therefore, it is required that product development focus should be a more humanistic-based approach that allows for creativity, rather than a plain mechanical system. This advocates for building or enhancing employees' knowledge sharing based on their skillsets and experiences (both successes and failures), imbibing flexibility to adore their creativity, and then integrating them into the product development aspects of technical and mechani- 
Gadjah Mada International Journal of Business, May - August 2008, Vol. 10, No. 2

cal states. This shall arrest the hindrance in their mental capabilities that limit the scope of innovation.

However, one should note that a line of difference exists between all manufacturing organizations in terms of product and process complexities, market patterns, technological development. Furthermore, there are costs related to each one of them that make it quite difficult to analyze and understand as to which variables can be attributed the most significant for product development in Indian manufacturing. This study is an initiative that intends to highlight about how the manufacturing organizations can integrate product development by looking at these two perspectives.

\section{References}

Bennett, R., and S. Savani. 2004. New product development practices of urban regeneration units: A comparative international study. International Journal of Nonprofit and Voluntary Sector Marketing 9 (4): 291-308.

Bhattacharya, S., V. Krishnan, and V. Mahajan. 1998. Managing new product definition in highly dynamic environments. Management Science 44 (11): S50 - S64

Bond III, E. U., and M. B. Houston. 2003. Barriers to matching new technologies and market opportunities in established firms. The Journal of Product Innovation Management: 120-135.

Calantone, R., R. Garcia, and C. Droge. 2003. The effects of environmental turbulence on new product development strategy planning. The Journal of Product Development Innovation: 90-103.

Clark, K., and T. Fujimoto. 1991. Product Development Performance: Strategy, Organization and Management in the World Auto Industry. Boston: Harvard Business Press.

Copper, R. G. 2001. Project newprod: Factors in new product success. European Journal of Marketing 14 (6): 277-292.

Datar, S., and J. C. Clark. 1997. Advantages of time-based new product development in a fast-cycle industry. Journal of Marketing Research 34 (Issue 1).

Davenport, T. H., and P. Laurece. 1998. Working Knowledge: How Organization Manage What They Know. Boston: Harvard Business School Press.

Davis, J, A. Fusfeld, E. Scriven, and G. Tritle. 2001. Determining a project's probability of success. Research Technology Management (May-June): 51-57.

Drucker, P. 1985. Innovation and Entrepreneurship: Practice and Principles (Drucker Series). Butterworth-Heinemann (Reprint).

Enright, M. 2001. Approaches to market orientation and new product development in smaller enterprises: a proposal for a context rich interpretive framework. Journal of Strategic Marketing: 301-313. 
Dutt-Product Development Categorized as Independent Strategic and Innovative Practice

Ettlie, J. E., and M. Subramaniam. 2004. Changing strategies and tactics for new product development. The Journal of Product Innovation Management: 95-109.

Filippini, R., L. Salmaso, and P. Tessarolo. 2004. Product development time performance: Investigating the effect of interactions between drivers. The Journal of Product Innovation Management: 199-214.

Hamel, G., and C. K. Prahalad. 1991. Corporate imagination and expeditionary marketing. Harvard Business Review (July-August): 81-92.

Hart, S. 1992. Dimensions of success in new product development: An exploratory investigation. In Whitelock et al., Marketing in the New Europe and Beyond.. Proceedings of the 1992 MEG Annual Conference.

Hill, P. 1998. The market research contribution to new product failure and success. Journal of Marketing Management: 269-277.

Johne, A., and P. Snelson. 1990. Successful product innovation in U.K and U.S firms. European Journal of Marketing: 7-21.

Joshi, A., and S. Sharma. 2004. Customer knowledge development: Antecedents and impact on new product performance. Journal of Marketing 68 (October): 47-59.

Kamath, U. V., N. Rajmohan, and V. V. Rao. 2000. Innovation - Strategy for Corporate Renaissance. All India Management Association: Excel Books (Reprint).

Kotler, P. 1998. Marketing Management - Planning, Analysis, Implementation and Control ( $9^{\text {th }}$ ed.). Prentice Hall Publication.

Krishnan, V., and K. T. Ulrich. 2001. Product development decisions: A review of the literature. Management Science: 1-21.

Ledwith, A. 2000. Management of new product development in small electronics firms. Journal of European Industrial Training: 137-148.

Levitt, T. 1986. The Marketing Imagination (New Expanded Edition). New York: Free Press (Reprint).

Li, T. and R. T. Calantone. 1998. The impact of market knowledge competence on new product advantage: Conceptualization and empirical examination. Journal of Marketing 62: 13-29.

Li, T., and T. S. Cavusgil. 2000. Decomposing the effects of market knowledge competence in new product development- a dimensionality analysis. European Journal of Marketing 34 (1/2): 57-79

Madhavan, R., and R. Grover. 1998. From embedded knowledge to embodied knowledge: New product development as knowledge management. Journal of Marketing 62: 112.

Mintzberg, H., J. Lampel, and B. Ahlstrand. 1998. Strategy Safari. New York L: Free Press.

Montoya, W., and Calantone. 1994. Determinants of NPD success. In A. Ledwith (2000), Management of new product development in small electronics firms. Journal of European Industrial Training: 137-148. 
Gadjah Mada International Journal of Business, May - August 2008, Vol. 10, No. 2

Moorman, C. 1995. Organizational market information processes: Cultural antecedents and new product. Journal of Marketing Research 32: 318-35.

Moorman, C. 1995. Organizational market information processes: Cultural antecedents and new product. Journal of Marketing Research 32: 318-35.

Moorman, C. and A. S. Miner. 1998. The convergence of planning and execution: Improvisation in new product development. Journal of Marketing 52: 1-20

Noble, G. W. 2006. The Emergence of the Chinese and Indian Automobile Industries and Implications for other Developing Countries (May): 4-9.

Nonaka, I., and H. Takeuchi. 1995. The Knowledge Creating Company: How Japanese Companies Create the Dynamics of Innovation. New York: Oxford University Press.

Olin, T., and A. B. Shani (Rami). 2003. NPD as a sustainable work process in a dynamic business environment. $R \& D$ Management: 1-13.

Perks, H., R. Copper, and C. Jones. 2005. Characterizing the role of design in new product development: An empirically derived taxonomy. The Journal of Product Innovation Management: 111-127.

Pun, K. F., and S. K. Chin. 2005. Online assessment of new product development performance: An approach. Total Quality Management 16 (2) (March): 157-169.

Rzakhanov, Z. 2004. Innovation, product development and market value: Evidence from the biotechnology industry. Econ. Innov. New Techn 13 (8) (December): 747-760.

Sethi, R., D. C. Smith, and C. W. Park. 2001. Cross functional product development teams, creativity, and the innovativeness of new consumer products. Journal of Marketing Research 38: 73-85.

Sherman, B., and Souder. 2005. New product development performance and the interaction of cross-functional integration and knowledge management. The Journal of Product Innovation Management: 399-411.

Sivadas, E., and F. R. Dwyer. 2000. An examination of organizational factors influencing new product success in internal and alliance-based processes. Journal of Marketing 64 (Issue 1).

Skyrme, D. 1999. Knowledge commerce: Succeeding in a global knowledge marketplace. Paper presented in Knowledge Economy Conference, Beijing, 1-3 Nov.

Song, M., and M. E. Parry. 1996. What separate Japanese new product winners from losers. The Journal of Product Innovation Management: 422-39.

Tatikonda, M. V., and M. M. Montoya-Weiss. 2001. Integrating operations and marketing perspectives of product innovation: The influence of organizational process factors and capabilities on development performance. Management Science 47 (1): 151172.

Thomke, S., and T. Fujimoto. 2000. The effect of 'Front-Loading' problem-solving on product development performance. Journal of Product Innovation Management 17: 128-142. 
Dutt-Product Development Categorized as Independent Strategic and Innovative Practice

Venkataramani, S. 2004. Accelerating product development in the automobile industry. International Journal of Manufacturing Technology and Management 6 (3-4) (1): 361-371.

Venugopal, R. 2005. Resource-based new product development: insights from the small car project of the Indian company TELCO International. Journal of Automotive Technology and Management 5 (1): 71 - 82.

Verona, G. 1999. A resource based view of product development. Academy of Management Review: 132-142

Veryzer, R. W., and B. Borja de Mozota. 2005. The impact of user-oriented design on new product development: An examination of fundamental relationships. The Journal of Product Innovation Management: 128-143.

Xie, J., M. Song, and A. Stringfellow. 2003. Antecedents and consequences of goal incongruity on new product development in five countries: A marketing view. The Journal of Product Innovation Management: 233-249.

Zack, M. H. 1999. Managing codified knowledge. Sloan Management Review 40 (4) (Summer): 45-58.

Zirger, B. Jo, and M. A. Maidique. 1990. A model of new product development: An empirical test. Management Science 36 (7): 867-883.

\section{Others References}

Department of Scientific and Industrial Research (DSIR) and FICCI. 'Enhancing India's Manufacturing Competitiveness by Leveraging Indian $R \& D$. www.ficci.com/press/ 160/MANUFACTURING.doc

National Manufacturing Competitiveness Council, Govt. of India. 2008. National Strategy for Manufacturing Report-2006. http://www.nmcc.nic.in/pdf/ strategy_paper_0306.pdf (Accessed on July 16, 2008).

Automotive Components Manufacturers Association (ACMA). 2005. India 2005-06 Report: 3-5.

Society for Indian Automobile Manufacturers (2007), http://www.siamindia.com/scripts/ industrystatistics.aspx. (September 11).

National Informatics Centre (2007). http://indiabudget.nic.in/es2006-07/chapt2007/ chap73.pdf. (September 9).

Association of Chambers of Commerce. 2006. Annual Report (2006): 112-134.

Federation of Indian Chambers of Commerce and Industry (FICCI). 2006-2007. Report on National Productivity: 34. 


\section{QUESTIONNAIRE}

\section{Part A:}

Respondent and Product Development Dept. Profile

1. NAME (Optional):

2. EDUCATION: Last Academic Degree Professional Degree/Diploma

3. DESIGNATION: DEPARTMENT:

4. WORK EXPERIENCE: __ Yrs. Months

5. Please indicate the firm's approximate gross sales or revenues for the last fiscal year. (TICK PLEASE)

No revenues Rs.500,000 to Rs. $1,000,000$

Less than Rs.250,000 Rs.250,000 to Rs.500,000

Rs.1,000,000 to Rs.5,000,000

Over Rs.5,000,000

6. Please provide the following information on the followings in the last fiscal year:

i. Research \& Development expenditures (in Rupees):

ii. R\&D expenditure on product development (in Rupees):

iii. Total employee in product development/mgmt. department:

iv. Percent of employee in the department with university degree:

\section{Part B:}

This part of the survey deals with two broad categories of product development process - One, strategic orientation of the organization towards product development and second, innovative urge of employee towards product development, as perceived by the product/project managers of development teams for their departments/centers.

\section{Strategic Orientation}

For each of the next statements please respond by ticking the number which best reflects your perceptions. The scale is as follows:

A score of 5: "Strongly agree"

A score of 4: "Agree

A score of 3: "Neither agree nor disagree

A score of 2: "Disagree"

A score of 1: "Strongly disagree" 
Dutt-Product Development Categorized as Independent Strategic and Innovative Practice

1. In this industry practical experience is more important than theoretical knowledge.

2. In a continuous process of product development, in this industry, it is very difficult to experiment

3. Only the employee, who is regularly involved in a particular job, will be in a position to suggest improvements.

4. This industry is so established that it is not amenable to major changes in terms of products.

5. Pace of growth in product development is majorly dependent on the leadership style of the CEO/functional head skills and exposure.

6. Traditionally, seniority is more respected than merit in our organization.

7. I feel organization is progressing only due to the efforts of the product development activities that we undertake.

8. In our product development departments/centers, information sharing is prompt and not confidential to product development only.

9. My superiors are more interested in routine work, than in experimenting with changes so, rapid product developments are less.

10. Even for small decision-making, we have lengthy procedures to seek approval.

11. I feel more financial powers will help me in executing fast the product development projects, reducing the lead time to market.

12. Liberalization has really made the new product development more competitive.

\section{Employee Innovative Aspect}

13. I always encourage my subordinates/team to come up with new ideas or improvements in product development on continuous basis.

14. More powers to team members will only result in misappropriation in the development activities.

15. I do not allow my subordinates to tamper with the day-to-day production and maintenance schedules, to experiment with any new idea.

16. I am so bogged down with administrative work that I am unable to think about any new ideas about developing more competitive products.

17. Many a time, I feel that my creative ideas are not adequately recognized and well received.

18. I discuss the problems faced during product development with a cross section of people like suppliers, contractors, customers apart from regular official peer group interactions. 
Gadjah Mada International Journal of Business, May - August 2008, Vol. 10, No. 2

19. If I am given an additional assignment, I will be able to accept it even without any additional resource or reward.

20. I read journals, watch over the industry news and hold membership of product development forums, associations etc. to keep myself updated.

21. Contribution by a hard working individual is more than the contribution by a creative individual.

22. I am ready to give suggestions for product improvements, provided implementation is assured.

23. Team members with less work load or lessen responsibility normally come up with a number of suggestions.

24. I feel uncomfortable to see my subordinate takes important decision without my prior permission.

25. If I feel that a new idea is good, I try to get it implemented with all earnestness, even against opposition.

26. Each team member should be rotated regularly in different types of jobs to gain wider exposure to developing innovative products.

27. Pace of growth in product development is highly dependent on the team leaders/project or product managers.

\section{Part C:}

This section of the survey deals with factors - both internal and external - to product development and drivers of the product development in the organization.

For each of the next statements please respond by ticking the number which best reflects your perceptions. The scale is as follows:

A score of 5: "Highest"

A score of 4: "High"

A score of 3: "Average"

A score of 2: "Low"

A score of 1: "Lowest"

28. How would you rank (out of scale of 5) the following internal factors' contribution to the product development process?

1. Cross-functional integration

2. Organizational culture \& politics

3. Hierarchy of structure

4. Customer focus (in terms of quality, and expertise of employee to deliver)

5. Strategy (say, time-to-market) and team leadership (of project leader) 
Dutt-Product Development Categorized as Independent Strategic and Innovative Practice

29. How would you rank (out of scale of 5) the following external factors contributing to product development process?

1. Product adaptation requirements

2. Market reforms (like, emission norms, dyes \& chemicals use etc)

3. Strategic alliances \& technology transfers

4. Supplier integration (for efficient development)

5. Technology inputs (CAD/CAM, and CRM, ERP etc. and then, websites)

30. Kindly now, rank the factors (out of scale of 5) to the extent that initiates/drives the product development process in your company most of the times?

1. Product maturity (in PLC)

2. Market potential and competency

3. Upgraded technological infrastructure

4. Creative urge for 'first mover advantage'

5. Stakeholders interest \& involvement

31. Rate the metrics listed below to show their significance in new product development process for your company?

1. Market potential \& competitiveness

1(lowest)_ 3 (avg)_ 5 (highest)

2. Technology changes (say, production methods)

1(lowest)_ 3 (avg)_ 5 (highest)

3. Experience, creativity \& innovation (like, in product designs, configuring better value)

1(lowest) 3 (avg) 5 (highest)

4. Managerial Interests \& execution style

1(lowest)_ 3 (avg)_5 (highest)

5. Pressure from suppliers and customers
1(lowest)
3 (avg)
5 (highest) 